Article

\title{
Anaerobic Oxidation of Methane in Freshwater Sediments of Rzeszów Reservoir
}

\author{
Dorota Szal *(D) and Renata Gruca-Rokosz \\ Department of Environmental and Chemistry Engineering, Faculty of Civil and Environmental Engineering and \\ Architecture, Rzeszów University of Technology, al. Powstańców Warszawy 12, 35-959 Rzeszów, Poland; \\ renatagr@prz.edu.pl \\ * Correspondence: d.piwinska@prz.edu.pl
}

Received: 27 October 2019; Accepted: 30 January 2020; Published: 2 February 2020

\begin{abstract}
The anaerobic oxidation of methane (AOM) is an important sink of methane that plays a significant role in global warming. However, evidence for the AOM in freshwater habitats is rare, especially in dam and weir (small-scale dam) reservoirs. Here, the AOM process was examined in freshwater sediments of a small-scale dam reservoir located in Rzeszów, SE Poland. The AOM rate was determined in the main experiment with the addition of the ${ }^{13} \mathrm{CH}_{4}$ isotope marker $\left(\mathrm{He}+{ }^{13} \mathrm{CH}_{4}\right)$. Sediments were collected three times: in spring (in May, $15^{\circ} \mathrm{C}$ ), in summer (in July, $20^{\circ} \mathrm{C}$ ) and in autumn (in September, $10^{\circ} \mathrm{C}$ ). Further analysis considers the impact on AOM rate of potential electron acceptors present in pore-water $\left(\mathrm{NO}_{2}{ }^{-}, \mathrm{NO}_{3}{ }^{-}, \mathrm{SO}_{4}{ }^{2-}\right.$, and $\mathrm{Fe}^{3+}$ ions). The work suggests that an $\mathrm{AOM}$ process does take place in the studied reservoir sediments, with this evidenced by the presence in the headspace of an increased ${ }^{13} \mathrm{CO}_{2}$ concentration deemed to derive from ${ }^{13} \mathrm{CH}_{4}$ oxidation. Rates of AOM noted were of $0.36-1.42 \mathrm{nmol} \cdot \mathrm{g}^{-1} \cdot \mathrm{h}^{-1}$, with the most intensive oxidation in each sediment layer occurring at $20^{\circ} \mathrm{C}$. While none of the potential electron acceptors considered individually were found to have had a statistically significant influence on the AOM rate, their significance to the dynamics of the AOM process was not precluded.
\end{abstract}

Keywords: anaerobic oxidation of methane; sediment incubation experiment; electron acceptors

\section{Introduction}

Methane $\left(\mathrm{CH}_{4}\right)$ is an important gaseous atmospheric pollutant contributing to the greenhouse effect through its capacity to capture heat 23 times more effectively than carbon dioxide $\left(\mathrm{CO}_{2}\right)$, as the best-known greenhouse gas. The oceans play a key role in global gaseous exchange, even though their share in the global carbon cycle is only of about $1 \%$ [1]. There is also strong evidence that inland waters (especially dam reservoirs) can play a role in the global dynamics of greenhouse gases that is disproportionate, given the way these cover just $3.6 \%$ of the Earth's surface [2,3], yet may well account for $16 \%$ of total $\mathrm{CH}_{4}$ emissions to the atmosphere [4-6].

Where reservoirs are concerned, it is organic matter decomposition that is responsible for the emission of both main GHGs, i.e., $\mathrm{CH}_{4}$ and $\mathrm{CO}_{2}[7,8]$. This decomposition takes place in sediments [9], though-as the main reducers are heterotrophic bacteria [10], which are most active is the upper sediment layer [11] —it is there that reduction prevails. Organic matter is the most frequent electron donor in the natural environment, but recent studies have shown how $\mathrm{CH}_{4}$ may also affect the growth of microorganisms under anaerobic conditions significantly [12]. This suggests a role for methane itself as an electron donor, with the acceptors being nitrates $\left(\mathrm{NO}_{3}^{-}\right)$, manganese $\left(\mathrm{Mn}^{4+}\right)$, iron $\left(\mathrm{Fe}^{3+}\right)$, or sulphates $\left(\mathrm{SO}_{4}{ }^{2-}\right)$. The use of electron acceptors by microorganisms is sequential, and the rate of methane oxidation would depend on their availability, though the actual presence of anaerobic oxidation of methane (AOM) in the environment was long doubted [13]. However, evidence has emerged in the 
last few years, with even a suggestion that the process has a significant role to play in the global carbon cycle [13-16]. AOM is considered to occur in both marine and freshwater sediments [17-22], to an extent that considerably reduces emissions of $\mathrm{CH}_{4}$ from waters to the atmosphere [16,23-25].

Given the results concerning $\mathrm{CH}_{4}$ emissions yielded by recent research on temperate-zone weir and dam reservoirs $[7,26]$, it is important for both the mechanisms underpinning AOM and the microorganisms involved in this oxidation of $\mathrm{CH}_{4}$ in freshwater ecosystems to be understood better, not least with a view to future $\mathrm{CH}_{4}$ emissions to the atmosphere being forecast appropriately. However, recent publications on the AOM process have focused on rates characterising marine sediments [27-34]. That leaves any further study of AOM rates in freshwater environments looking of value as it contributes to a broader understanding of the metabolic processes microorganisms in aquatic ecosystems are responsible for, above all the natural oxidation of $\mathrm{CH}_{4}$ by way of alternative electron acceptors.

It is the relative lack of information on AOM process in small-scale dam reservoirs that prompted the attempt described here to pursue preliminary research into this process, in the sediments of the small-scale dam reservoir located in Rzeszów, SE Poland. Specifically, the aim was to determine AOM rates in the main experiment involving the incubation of sediments along with an ${ }^{13} \mathrm{CH}_{4}$ isotope marker, at temperatures of 10,15 , or $20^{\circ} \mathrm{C}$. Additionally, for the purpose of comparison, an experiment in anaerobic conditions without addition ${ }^{13} \mathrm{CH}_{4}(\mathrm{He})$ was carried out.

\section{Materials and Methods}

\subsection{Study Area}

The reservoir in Rzeszów selected for the research was built in 1974 by damming Poland's River Wisłok some $64 \mathrm{~km}$ along its course with a concrete weir. The overflow weir section consists of 4 spans ( $20.8 \mathrm{~m}$ wide). The spans are closed with valves of $4.30 \mathrm{~m}$ high and movable flap gates, raising the water above the normal damming level by $1 \mathrm{~m}$. The ordinate of the normal damming level is $198.50 \mathrm{~m}$ a.s.l. Also fed by the River Strug, the reservoir has as its main purpose the proper operation of a water intake for the 184,000 inhabitant city of Rzeszów. However, due to a location on the outskirts of that city, this body of water also plays its important sporting and recreational role. That said, a proportionally large reduction in overall volume (of $0.7 \mathrm{M} \mathrm{m}^{3}$ ) has affected the Reservoir over the last 40 years, with many areas (in the upper part especially) silted up and gradually transforming into land.

Rzeszów Reservoir has an elongated shape and a variable width ranging from $40 \mathrm{~m}$ to $300 \mathrm{~m}$ and the mean depth is ca. $2 \mathrm{~m}$. The catchment of the reservoir covers $2050 \mathrm{~km}^{2}$, with the Wisłok flowing through a sub-mountainous (largely agricultural) area into a central industrialised part featuring glassworks, tanneries and refineries. For its part, the catchment of the Strug is agricultural land with high population density [35].

Reservoir sediments were sampled at a station located near the weir, following recent studies indicating that $\mathrm{CH}_{4}$ emissions there might be considerable, at $29.13 \pm 67.87 \mathrm{mmol} \cdot \mathrm{m}^{-2}$. day $^{-1}$ on average [7]. $\mathrm{CH}_{4}$ production is shown to result from processes of acetate fermentation and hydrogenotrophic methanogenesis, albeit with the relative significances of these varying with temperature and sediment layer [36,37]. The locations of Rzeszów Reservoir and the sampling station are shown in Figure 1.

\subsection{Sediment Sampling and Preparation}

Reservoir sediments were collected in spring, summer and autumn in 2018, at temperatures of 15,20 , and $10^{\circ} \mathrm{C}$, respectively. Specifically, sampling took place once time each in April, July, and September, with five cores sampled at the bottom of some $1 \mathrm{~m}$ water depth using a specially designed sediment corer with a 60-mm-diameter (Polish patent application No P.428513) along with overlying water. These were then transported to the laboratory immediately, with the cores (thickness of sediment cores usually no higher than $15-20 \mathrm{~cm}$ ) pushed progressively from the bottom of Plexiglas 
tubes by a piston, in such a way that it was possible to study separately the layers present at depths of $0-5,5-10$, and $10-15 \mathrm{~cm}$.

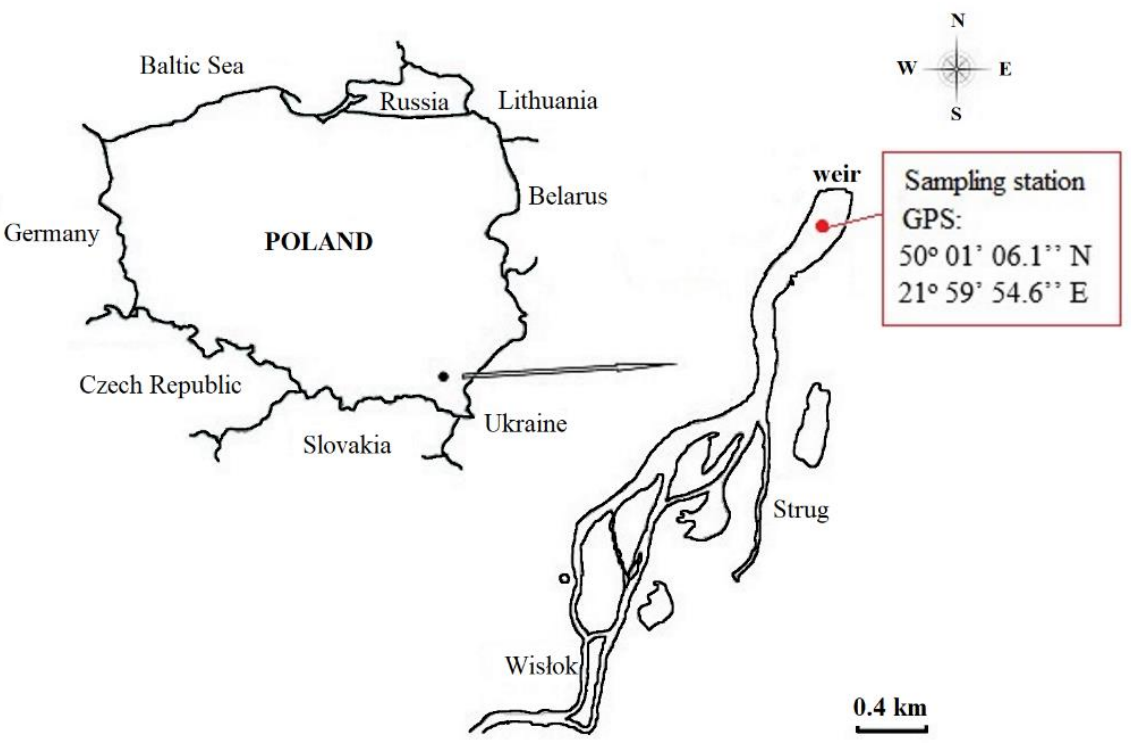

Figure 1. Location of Rzeszów Reservoir and the sampling station

Pore-water was centrifuged from three layers of one core in a laboratory centrifuge (MPW-352), so that determinations could be made for organic carbon (TOC), as well as nitrite, nitrate, and sulphate ions $\left(\mathrm{NO}_{2}{ }^{-}, \mathrm{NO}_{3}{ }^{-}\right.$, and $\left.\mathrm{SO}_{4}{ }^{2-}\right)$. Pore-water from a second core was squeezed directly into a gastight vial using a modified pore-water squeezer [38], in order for contact with the atmosphere to be avoided, so that a determination for trivalent iron $\left(\mathrm{Fe}^{3+}\right)$ could be carried out.

The three sediment layers from the third core were dried to constant weight at room temperature, and subsequently at $60^{\circ} \mathrm{C}$, before sediments were milled in advance of parameters like $\mathrm{pH}$, organic matter (OM), total organic carbon (TOC), total nitrogen (TN), and humic substances (HS) being determined. The grain size distribution of sediments was determined only once in summer (in July).

Sediments from the fourth and fifth cores were used to research the AOM process (via incubations with the isotope marker $\left(\mathrm{He}+{ }^{13} \mathrm{CH}_{4}\right)$ and without $\left.{ }^{13} \mathrm{CH}_{4}(\mathrm{He})\right)$.

\subsection{Incubation Experiment}

After being brought to the laboratory, the collected sediments were divided into their 0-5, 5-10, and 10-15 cm layers. The sediments of each layer were homogenized by gentle mixing using a glass rod. To avoid any exposure to the atmospheric oxygen, it was all done inside the glove box under an inert atmosphere of helium. Incubation of each layer then took place, with the ${ }^{13} \mathrm{CH}_{4}$ isotope marker added or without ${ }^{13} \mathrm{CH}_{4}$. For this purpose, $7 \mathrm{~g}$ of wet sediment from each layer was placed into the incubation vessels $\left(120 \mathrm{~cm}^{3}\right)$ with $14 \mathrm{~mL}$ of distilled water deoxygenated by nitrogen purging $(99.99 \%$ Air Products) using a laboratory scrubber. All operations were carried out in a glove box (830-ABB Compact Glove Box Plas-Labs, Inc. USA). Prior to the laboratory work, the air in the glove box was replaced 7-8 times, with helium (He, 99.9999\% Air Products). Prepared samples were then subjected to pre-incubation by placing them in the dark in a thermostat for 10 days at in situ temperature $\left(15^{\circ} \mathrm{C}\right.$ spring; $20^{\circ} \mathrm{C}$ summer; $10{ }^{\circ} \mathrm{C}$ autumn), to allow for the removal of residual oxygen by microorganisms, via biochemical processes. It was only after this that about $1 \mathrm{~cm}^{3}$ of the ${ }^{13} \mathrm{CH}_{4}$ isotope marker $(99 \%$, Sigma-Aldrich 490229-1L-EU) was added to samples. Incubations were carried out at temperatures corresponding to the in-situ sediment temperatures in spring $\left(15^{\circ} \mathrm{C}\right)$, summer $\left(20^{\circ} \mathrm{C}\right)$ and autumn $\left(10^{\circ} \mathrm{C}\right)$. After a certain time $(0,3,20$, and 40 days in the spring and summer cases; and $0,3,10,20$, 30,40 and 50 in autumn), $1 \mathrm{~cm}^{3}$ of the headspace was withdrawn carefully within the glove box 
using a gas-tight syringe (1001SL Hamilton) and analyzed for $\mathrm{CH}_{4}$ and $\mathrm{CO}_{2}$ concentrations (ppm) using a Shimadzu GC-2010 Plus gas chromatograph equipped with a Barrier Discharge Ionization Detector (BID) and a Shin Carbon ST column (2 m, $1.00 \mathrm{~mm}$ ID, Mesh 100/120). Samples were injected manually into a GC apparatus with the detector working at $250{ }^{\circ} \mathrm{C}$. Temperatures were $150{ }^{\circ} \mathrm{C}$ for the injection port and $60^{\circ} \mathrm{C}$ for the column (the latter being maintained for $13 \mathrm{~min}$ ). The carrier gas was helium (99.9999\% Air Products) at a $50 \mathrm{~mL} \cdot \mathrm{min}^{-1}$ flow rate. The carbon isotopic composition of $\mathrm{CO}_{2}$ was determined using gas chromatograph combustion isotope mass spectrometry (GC-CIII-IRMS

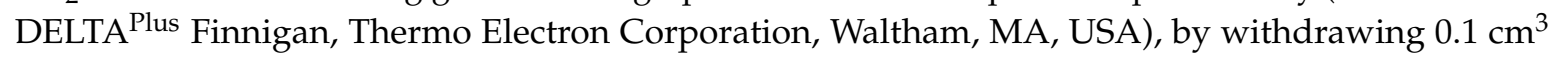
of the headspace (also in the glove box) using a gas-tight syringe (1700, Hamilton). The results of stable isotope analyses are presented in the form of $\delta^{13} \mathrm{C}$ expressed in [\%o] relative to the PDB (Pee Dee Belemnite) standard (Equation (1)):

$$
\delta^{13} C=\left({ }^{13} C /{ }^{12} C_{(\text {sample })}\right) /\left({ }^{13} C /{ }^{12} C_{(s t d)}-1\right) \times 1000
$$

Results obtained for $\mathrm{CO}_{2}$ concentrations (ppm) and $\delta^{13} \mathrm{C}-\mathrm{CO}_{2}(\%$ o) were used to calculate the rate at which the anaerobic oxidation of methane (AOM) had taken place.

In order to confirm the anaerobic conditions, empty vials were prepared (without sediment and distilled water) according to the procedure described above. The ${ }^{13} \mathrm{CH}_{4}$ isotope marker alone was added to the vials and the concentrations of $\mathrm{CH}_{4}$ and $\mathrm{CO}_{2}$ were determined (at the same days as for other samples). There was no oxidation of $\mathrm{CH}_{4}$ to $\mathrm{CO}_{2}$ and therefore no oxygen.

The $\mathrm{CH}_{4}$ and $\mathrm{CO}_{2}$ concentrations at time zero were subtracted from each $\mathrm{CH}_{4}$ and $\mathrm{CO}_{2}$ concentrations, respectively, after incubation times of $3,10,20,30,40$, and 50 days.

\subsection{Sediment and Pore-Water Analysis}

The reaction was determined potentiometrically (MultiLine P4, WTW, Germany) in slurry with $1 \mathrm{~N} \mathrm{KCl}[39]$.

The OM content was determined as the loss after drying of sediments within $4 \mathrm{~h}$ at $550{ }^{\circ} \mathrm{C}$ [40].

Areometric method was used in determining the grain size distribution of sediments. The procedure for the determination of the grain size distribution is described in detail in PKN-CEN ISO/TS 17892-4: Part 4.

The contents of TOC and TN were determined at $1020^{\circ} \mathrm{C}$ using a $\mathrm{CN}$ elemental analyzer (Flash EA 1112, ThermoQuest). The quality analysis made use of standard samples of known amounts of carbon and nitrogen (acetanilide). Prior to determination of TOC content, the dried and ground sediment samples were placed in a desiccator with concentrated $\mathrm{HCl}$ vapor [41] for $72 \mathrm{~h}$, to ensure the removal of carbonates. Prior to analysis, the sediment sample was again dried to constant weight at $60^{\circ} \mathrm{C}$.

The modified method of Griffith and Schnitzer (1975) [42] was used for determining the content of humic substances. Dried and milled sediments were shaken at room temperature with 0.1 mole $\mathrm{NaOH}$. A known volume of the alkaline extract was taken into a centrifuge tube, the solution then being adjusted to $\mathrm{pH} 1.0-1.5$ with $\mathrm{H}_{2} \mathrm{SO}_{4}$, and allowed to stand for the next day to precipitate humic acids. Following separation from the precipitate, the obtained solution was then the subject of determinations for the organic-carbon content of fulvic acid (FA). The organic-carbon content of fulvic plus humic acids $(\mathrm{FA}+\mathrm{HA})$ was determined in the remaining alkaline extract using the Shimadzu TOC-V CPN Total Organic Carbon Analyzer. 0.5 $\mathrm{M} \mathrm{H}_{2} \mathrm{SO}_{4}$ was added to residue in the centrifuge tube, and the tubes placed in a water bath for $1 \mathrm{~h}$ at $80^{\circ} \mathrm{C}$. In the extract obtained, the organic carbon content of the hemicellulose (HC) was determined on the aforementioned analyzer. The residue in the centrifuge tube was dried at $80^{\circ} \mathrm{C}$ to constant weight and weighed carefully. A sample of the remaining sediment was taken, to determine the organic carbon content of humins (HU) using a $\mathrm{CN}$ elemental analyzer (Flash EA 1112, ThermoQuest). The organic carbon content of humic substances was calculated as the sum of the organic carbon content of the fulvic acids (FA), humic acids (HA) and humins (HU). 
Ions, i.e., nitrite $\left(\mathrm{NO}_{2}{ }^{-}\right)$, nitrate $\left(\mathrm{NO}_{3}{ }^{-}\right)$, and sulphate $\left(\mathrm{SO}_{4}{ }^{2-}\right)$, were analysed in centrifuged pore-water after first being filtered through $0.22-\mu \mathrm{m}$ syringe filters using DIONEX ICS-5000 ion chromatography.

Total organic carbon was determined using the Shimadzu TOC-V CPN Total Organic Carbon Analyzer, while the concentration of $\mathrm{Fe}^{3+}$ was determined spectrophotometrically using ferrozine, in line with the method after Viollier et al. (2000) [43]. Absorbance was measured using a Hach UV-VIS spectrometer at $562 \mathrm{~nm}$.

\subsection{Calculations}

The AOM rate $\left(\mathrm{nmol} \cdot \mathrm{g}^{-1} \cdot \mathrm{h}^{-1}\right)$ and amount of $\mathrm{CH}_{4}$ oxidised $\left(\mathrm{nmol} \cdot \mathrm{g}^{-1}\right.$ ) were calculated using formula developed by reference to available literature $[44,45](2)$ and $(3) . \delta^{13} \mathrm{C}-\mathrm{CO}_{2}$ was converted to ${ }^{13} \mathrm{C}$ atom percent $\left({ }^{13} \mathrm{C}\right.$ AT\%) in line with Equation (4):

$$
\begin{aligned}
& A O M\left(\mathrm{nmol} \mathrm{g}^{-1} \mathrm{~h}^{-1}\right)= \\
& \left(\frac{13 \mathrm{CAT} \%}{100} \times\left[\mathrm{CO}_{2}\right](\mathrm{ppm}) \times\left(V_{g}\left(\mathrm{dm}^{3}\right) / V_{m}\left(\frac{d m^{3}}{m o l}\right)\right) \times 1000\right) /(m(g) \times t(h)) \\
& C H_{4} \text { oxidised }\left(\mathrm{nmol} \mathrm{g}^{-1}\right)=A O M \times t(h) \\
& \left(\left[{ }^{13} \mathrm{CAT}=\left(\delta^{13} \mathrm{CPDB}+1000 / \delta^{13} \mathrm{CPDB}+1000+\frac{1000}{R_{s t d}}\right) \times 100=\right.\right. \\
& \left.\left.\left[{ }^{13} \mathrm{CO}_{2}\right]+\left[{ }^{12} \mathrm{CO}_{2}\right]\right)\right) \times 100=\left(\left[{ }^{13} \mathrm{CO}_{2}\right] /\left[\mathrm{CO}_{2}\right]\right) \times 100
\end{aligned}
$$

where ${ }^{13} \mathrm{CAT}-{ }^{13} \mathrm{C}$ atom percent $(\%) ; \mathrm{CO}_{2}$ - carbon dioxide concentration at time $\mathrm{t}(\mathrm{ppm}) ; \mathrm{V}_{\mathrm{g}}$ - volume of headspace in vial $\left(0.096156 \mathrm{dm}^{3}\right) ; \mathrm{V}_{\mathrm{m}}$-molar volume of ideal gas at $25^{\circ} \mathrm{C}\left(24.45 \mathrm{dm}^{3} \cdot \mathrm{Cmol}^{-1}\right) ; \mathrm{m}-\mathrm{dry}$ sediment weight $(\mathrm{g}) ; \mathrm{t}$-incubation time $(\mathrm{h}) ; \mathrm{R}_{\mathrm{std}}$ —absolute ratio constants in the standard (0.0111803).

\section{Results}

\subsection{Characteristics of Sediments and Pore-Water}

\begin{tabular}{|c|c|c|c|c|c|c|c|}
\hline Temperature & Depth $[\mathrm{cm}]$ & pH [-] & OM [\%] & TOC [\%] & TN [\%] & TOC:TN [-] & HS [mg.g-1 d.w.] \\
\hline \multirow{3}{*}{$10^{\circ} \mathrm{C}$} & $0-5$ & 7.20 & 10.84 & 3.62 & 0.37 & 9.86 & 31.7 \\
\hline & $5-10$ & 7.20 & 9.09 & 2.89 & 0.27 & 10.69 & 27.5 \\
\hline & $10-15$ & 7.39 & 6.46 & 1.82 & 0.17 & 10.81 & 17.6 \\
\hline \multirow{3}{*}{$15^{\circ} \mathrm{C}$} & $0-5$ & 7.51 & 9.65 & 3.79 & 0.34 & 11.16 & 34.9 \\
\hline & $5-10$ & 7.58 & 8.18 & 3.84 & 0.29 & 13.36 & 34.7 \\
\hline & $10-15$ & 7.71 & 5.99 & 2.66 & 0.17 & 15.26 & 22.9 \\
\hline \multirow{3}{*}{$20^{\circ} \mathrm{C}$} & $0-5$ & 7.15 & 9.30 & 2.90 & 0.28 & 10.33 & 27.7 \\
\hline & $5-10$ & 7.27 & 7.95 & 2.31 & 0.23 & 10.28 & 22.1 \\
\hline & $10-15$ & 7.54 & 4.62 & 1.27 & 0.10 & 12.21 & 11.9 \\
\hline \multirow{5}{*}{$\begin{array}{l}\text { Granulometric } \\
\text { composition }\end{array}$} & & & Fraction [\%] & & & Type & \\
\hline & & $\begin{array}{c}\text { Fsa } \\
2-0.063\end{array}$ & $\begin{array}{c}\text { Fsi } \\
0.063-0.002\end{array}$ & $\begin{array}{l}\mathrm{Fcl}< \\
0.002\end{array}$ & \multicolumn{3}{|c|}{ PN-EN ISO 14688-1:2018-05 } \\
\hline & $0-5$ & 3.5 & 77.35 & 19.15 & \multirow{3}{*}{\multicolumn{3}{|c|}{$\begin{array}{l}\text { silty loam }(\mathrm{clSi}) \\
\text { silty clay }(\mathrm{siCl}) \\
\text { silty clay }(\mathrm{siCl})\end{array}$}} \\
\hline & $5-10$ & 5.23 & 73.15 & 21.61 & & & \\
\hline & $10-15$ & 4.01 & 73.76 & 22.22 & & & \\
\hline
\end{tabular}

\subsubsection{Sediment Characteristics}

The results for selected physical and chemical parameters characterising sediments of Rzeszów Reservoir are as summarised in Table 1.

Table 1. Selected physical and chemical parameters characterising sediments of Rzeszów Reservoir. 
The reaction of the sediments proved to be slightly alkaline, with $\mathrm{pH}$ values in the 7.15-7.71 range. The lowest $\mathrm{pH}$ characterised the sediments of the $0-5 \mathrm{~cm}$ layer, and the highest the 10-15 cm layer. The highest $\mathrm{OM}$ values were likewise noted for the uppermost $5 \mathrm{~cm}$ layer (in the range $9.30-10.84 \%$ d.m.). Lower OM values were noted for the $10-15 \mathrm{~cm}$ layer (4.62-6.46\%). The organic carbon content (TOC) was found to correlate significantly with that of OM content $\left(\mathrm{R}^{2}=0.65\right)$, with figures for TOC being approximately $30 \%$ of OM values. Sediments were also characterised by low TN contents-in the range $0.10 \%\left(10-15 \mathrm{~cm}-20{ }^{\circ} \mathrm{C}\right.$ layer $)$ to $0.37 \%\left(0-5 \mathrm{~cm}\right.$ layer- $\left.10{ }^{\circ} \mathrm{C}\right)$. There were positive correlations between the content of OM and TN $\left(R^{2}=0.95\right)$ as well as TOC and TN $\left(R^{2}=0.82\right)$, with this indicating organic nitrogen as the main component of TN. The OM and TOC contents are rather typical for Polish reservoirs. For example, the sediments in Sulejów Reservoir have OM contents in the 9.9-21.8\% range, as well as TOC values of 5.2-10.3\% [46]. In the sediments of Czorsztyn Reservoir, the OM values ranged from $2.3-11.9 \%$ [47], while corresponding values for other reservoirs are: Solina $8.72-10.11 \%$ OM and 1.94-2.92\% TOC; Myczkowce 10.78-11.94\% OM and 3.95-4.08\% TOC [48,49].

C:N ratios obtained for the present study are in the 9.86-15.26 range, albeit with higher values observed in the deepest $(10-15 \mathrm{~cm})$ sediment layer. Lower $C: N$ values recorded in the $0-5 \mathrm{~cm}$ layer indicate a greater share of autochthonous matter; in turn, organic matter in the 10-15 cm sediment layer is mainly of allochthonous origin, with sources taken to include macrophytes and plants rich in cellulose [7].

The content of humic substances ranged from 11.9 to $34.9 \mathrm{mg} \cdot \mathrm{g}^{-1} \mathrm{~d} . \mathrm{w}$. The highest values were obtained in the uppermost $5 \mathrm{~cm}$ sediment layer in each research season. The content of humic substances correlated positively with the content of organic matter, and $\mathrm{R}^{2}$ was 0.70 .

All analysed sediment layers consisted of several fractions (Table 1). In all layers, the predominant fraction was the silty fraction and its content varied from $73.15 \%$ to $77.35 \%$. The sand fraction represented the smallest contribution in the granulation of the studied sediments and ranged from $3.50 \%$ to $5.23 \%$. The remaining share was a clay fraction. The analysis of the grain composition of sediments showed that the grain fraction of $0.063-0.002 \mathrm{~mm}$ dominated in all sediment layers. In addition, the $2-0.063 \mathrm{~mm}$ fraction represented the lowest share. The top $5 \mathrm{~cm}$ sediment layer was granulometrically equivalent to silty loam, the deeper layers were granulometrically equivalent to silty clay.

\subsubsection{Pore-Water Characteristics}

Values for pore-water concentrations of the $\mathrm{NO}_{2}{ }^{-}, \mathrm{NO}_{3}{ }^{-}, \mathrm{SO}_{4}{ }^{2-}$, and $\mathrm{Fe}^{3+}$ ions, as well as TOC are as shown in Table 2.

Table 2. Results for chemical parameters of pore-water in Rzeszów Reservoir sediments.

\begin{tabular}{|c|c|c|c|c|c|c|}
\hline Temperature & $\begin{array}{c}\text { Depth } \\
{[\mathrm{cm}]}\end{array}$ & $\begin{array}{c}\mathrm{NO}_{2}^{-} \\
{\left[\mathrm{mg} \cdot \mathrm{dm}^{-3}\right]}\end{array}$ & $\begin{array}{c}\mathrm{NO}_{3}^{-} \\
{\left[\mathrm{mg} \cdot \mathrm{dm}^{-3}\right]}\end{array}$ & $\begin{array}{c}\mathrm{SO}_{4}^{2-} \\
{\left[\mathrm{mg} \cdot \mathrm{dm}^{-3}\right]}\end{array}$ & $\begin{array}{c}\text { TOC } \\
{\left[\mathrm{mg} \cdot \mathrm{dm}^{-3}\right]}\end{array}$ & $\begin{array}{c}\mathrm{Fe}^{3+} \\
{\left[\mu \mathrm{mol} \cdot \mathrm{dm}^{-3}\right]}\end{array}$ \\
\hline \multirow{3}{*}{$10^{\circ} \mathrm{C}$} & $0-5$ & 0.017 & 0.017 & 0.230 & 20.39 & 380.57 \\
\hline & $5-10$ & 0.014 & 0.019 & 0.036 & 13.18 & 182.80 \\
\hline & $10-15$ & 0.021 & 0.017 & n.d. & 16.47 & 95.40 \\
\hline \multirow{3}{*}{$15{ }^{\circ} \mathrm{C}$} & $0-5$ & 0.015 & 0.973 & 13.867 & 79.88 & 279.75 \\
\hline & $5-10$ & n.d. & 0.052 & 2.556 & 31.44 & 177.15 \\
\hline & $10-15$ & n.d. & 0.020 & 0.373 & 36.56 & 39.45 \\
\hline \multirow{3}{*}{$20^{\circ} \mathrm{C}$} & $0-5$ & 0.014 & 0.034 & 0.508 & 6.32 & 351.11 \\
\hline & $5-10$ & 0.009 & 0.025 & 0.256 & 5.62 & 248.32 \\
\hline & $10-15$ & 0.013 & 0.055 & 0.986 & 26.18 & 46.85 \\
\hline
\end{tabular}

n.d.-not detected.

In each of the three seasons researched, the highest concentrations were obtained for TOC $\left(5.62-79.88 \mathrm{mg} \cdot \mathrm{dm}^{-3}\right)$. Values on average 100 times lower characterised $\mathrm{NO}_{2}{ }^{-}\left(0.009-0.021 \mathrm{mg} \cdot \mathrm{dm}^{-3}\right)$, 
$\mathrm{NO}_{3}{ }^{-}\left(0.017-0.973 \mathrm{mg} \cdot \mathrm{dm}^{-3}\right)$ and $\mathrm{SO}_{4}{ }^{2-}\left(0.036-13.867 \mathrm{mg} \cdot \mathrm{dm}^{-3}\right)$. On the other hand, $\mathrm{Fe}^{3+}$ concentrations were of $39.45-380.57 \mu \mathrm{mol} \cdot \mathrm{dm}^{-3}$.

\subsection{Rates of Anaerobic Oxidation of Methane}

Changes in $\mathrm{CH}_{4}$ and $\mathrm{CO}_{2}$ concentrations in the headspace during the incubation of sediments $\left(\mathrm{He}+{ }^{13} \mathrm{CH}_{4}\right)$ at different temperatures are as shown in Supplementary Figure S1.

The concentration of $\mathrm{CH}_{4}$ was already decreasing rapidly in the first 3 days, only to reach values below $10 \mathrm{ppm}$ on the last day of incubation (day 40 or 50). In contrast, as time went by, there was a steady increase in the concentration of $\mathrm{CO}_{2}$ recorded from the headspace. Values noted for $\mathrm{CH}_{4}$ were in the 0.3-2200 ppm range, while those of $\mathrm{CO}_{2}$ varied from 2200 to $18,000 \mathrm{ppm}$. At time zero, the values obtained were, in turn, in the 13-7910 ppm $\left(\mathrm{CH}_{4}\right)$ and $1610-6760 \mathrm{ppm}\left(\mathrm{CO}_{2}\right)$ range. However, by day 50 of the research $\left(\right.$ at $10^{\circ} \mathrm{C}$ ) there had been a decrease in $\mathrm{CO}_{2}$ concentration perhaps indicating the gradual depletion of electron acceptors, and hence increased emphasis on the process of methanogenesis most probably proceeding simultaneously the entire time.

Results obtained for $\mathrm{CH}_{4}$ and $\mathrm{CO}_{2}$ concentrations via He experiment are as shown in the Supplementary Figure S2. In the case of treatment without ${ }^{13} \mathrm{CH}_{4}, \mathrm{CH}_{4}$ concentrations in the headspace varied from 1 to $50 \mathrm{ppm}$, while those of $\mathrm{CO}_{2}$ were in the 1400-16000 ppm range. Additionally, $\mathrm{CH}_{4}$ and $\mathrm{CO}_{2}$ concentrations at 0 day equaled 11-95 ppm and 900-10100 ppm, respectively.

Further analysis considers the calculation of ${ }^{13} \mathrm{C}$ atom percent $\left({ }^{13} \mathrm{C} \mathrm{AT} \%\right)$, on the basis of $\delta^{13} \mathrm{C}-\mathrm{CO}_{2}$ $(\%$ o) values, and the results are shown in the Supplementary Materials (Figure S3).

$\mathrm{CO}_{2}$ in the headspace was found to be significantly enriched in ${ }^{13} \mathrm{C}$, most of all in the case of samples incubated at $20{ }^{\circ} \mathrm{C}$. At this temperature, values noted for ${ }^{13} \mathrm{C}$ AP were in the range $2.51-3.10 \%$ in the $0-5 \mathrm{~cm}$ layer (Supplementary Materials-Figure S3c), $4.82-6.77 \%$ in the $5-10 \mathrm{~cm}$ layer (Supplementary Materials-Figure S3f) and 2.13-7.62\% in the 10-15 cm layer (Supplementary Materials-Figure S3i). In the case of other temperatures, values obtained were on average only half as high $\left(15^{\circ} \mathrm{C}\right.$-Supplementary Figure S3b,e,h) or only one-third as high $\left(10^{\circ} \mathrm{C}\right.$ Supplementary Figure $\mathrm{S} 3 \mathrm{a}, \mathrm{d}, \mathrm{g})$. In most cases, ${ }^{13} \mathrm{C}$ AP values decreased beyond day 20 of the incubation process. On the other hand, no significant increase in the ${ }^{13} \mathrm{C} \mathrm{AP}$ of He treatment (without ${ }^{13} \mathrm{CH}_{4}$ ) was noted, which indicated that natural fractionation had little impact over the course of the experiment, and that natural ${ }^{13} \mathrm{CO}_{2}$ signature does not change over the trial. The values obtained remain at a similar level at different temperatures in sediment layers. ${ }^{13} \mathrm{C}$ AP were below $1.30 \%$.

The AOM rate and amount of $\mathrm{CH}_{4}$ oxidised, as calculated on the basis of $\mathrm{CO}_{2}$ concentrations (ppm) and $\delta^{13} \mathrm{C}-\mathrm{CO}_{2}$ values (\%o), are shown graphically in Figure 2.

The AOM rate and amount of $\mathrm{CH}_{4}$ oxidised were greater at progressively-higher temperatures, with values for $\mathrm{AOM}$ noted at $20^{\circ} \mathrm{C}$ in fact being five times higher than those at 10 or $15^{\circ} \mathrm{C}$. However, while the AOM process at $20^{\circ} \mathrm{C}$ proved most effective in the $5-10 \mathrm{~cm}$ layer, those ongoing at 10 and $15^{\circ} \mathrm{C}$ peaked in the $0-5 \mathrm{~cm}$ layer. Irrespective of incubation type, lowest values for the AOM process were noted in sediments from $10-15 \mathrm{~cm}$ down. At $10^{\circ} \mathrm{C}$, the amount of $\mathrm{CH}_{4}$ oxidised did not exceed $100 \mathrm{nmol} \cdot \mathrm{g}^{-1}$, while at $15^{\circ} \mathrm{C}$ amounts were still below $400 \mathrm{nmol} \cdot \mathrm{g}^{-1}$. These results were thus in contrast with those obtained at $20^{\circ} \mathrm{C}$, which even reached $1000 \mathrm{nmol} \cdot \mathrm{g}^{-1}$.

The AOM rate generally peaked as soon as on day 3 of incubation, with a decrease over time then ensuing. This shaping of the rate most likely reflected gradual depletion of electron acceptors involved in the AOM process [50].

The AOM rate and amount of $\mathrm{CH}_{4}$ oxidised, i.e., He treatment, are shown graphically in Figure 3.

In the case of the incubation without ${ }^{13} \mathrm{CH}_{4}$, the AOM rate reached the highest values in the $0-5 \mathrm{~cm}$ layer, and did not exceed $0.5 \mathrm{nmol} \cdot \mathrm{g}^{-1} \cdot \mathrm{h}^{-1}$. The rates then decreased with depth. Values for AOM obtained at $20^{\circ} \mathrm{C}$ were higher compared to other temperatures. The amount of $\mathrm{CH}_{4}$ oxidised were almost $200 \mathrm{nmol} \cdot \mathrm{g}^{-1}$ in the $0-5 \mathrm{~cm}$ layer, on the other hand, in the $10-15 \mathrm{~cm}$ layer amounts were below $100 \mathrm{nmol} \cdot \mathrm{g}^{-1}$. 
a) $0-5 \mathrm{~cm}$

b) $5-10 \mathrm{~cm}$
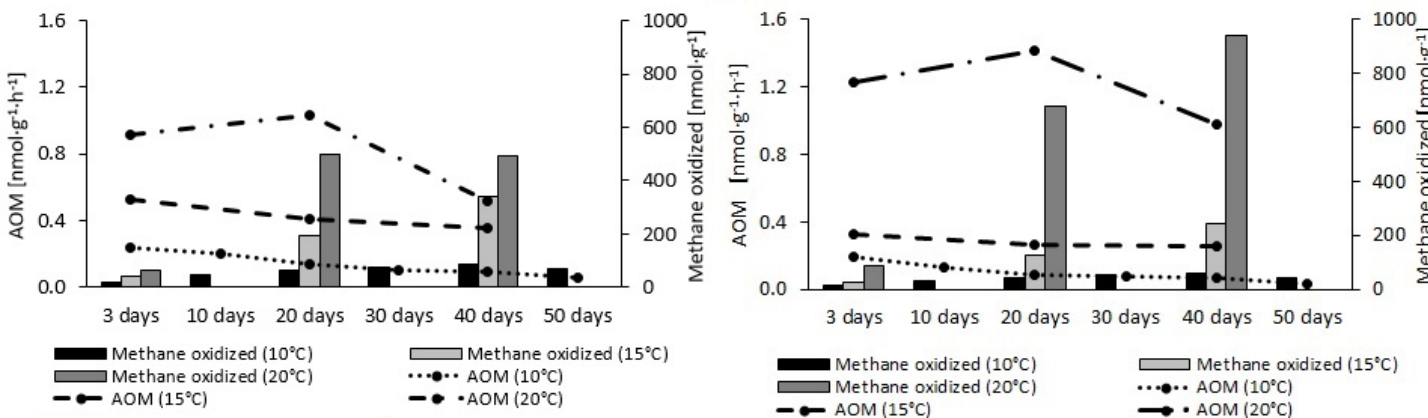

c) $10-15 \mathrm{~cm}$

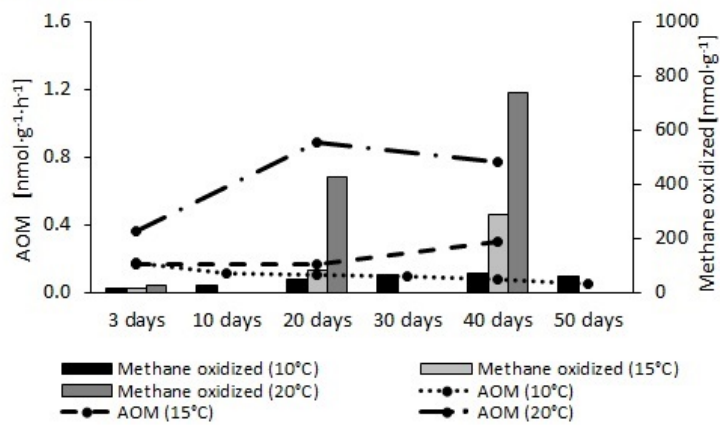

Figure 2. Changes through time in the $\mathrm{AOM}$ rate and amount of $\mathrm{CH}_{4}$ oxidised, for the sediment layers collected from 0-5 cm (panel a), 5-10 cm (panel b) and 10-15 cm (panel c) $\left(\mathrm{He}+{ }^{13} \mathrm{CH}_{4}\right)$.

a) $0-5 \mathrm{~cm}$

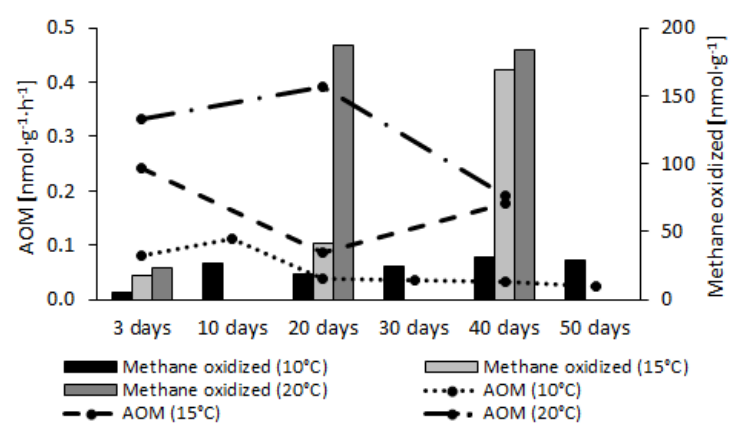

c) $10-15 \mathrm{~cm}$

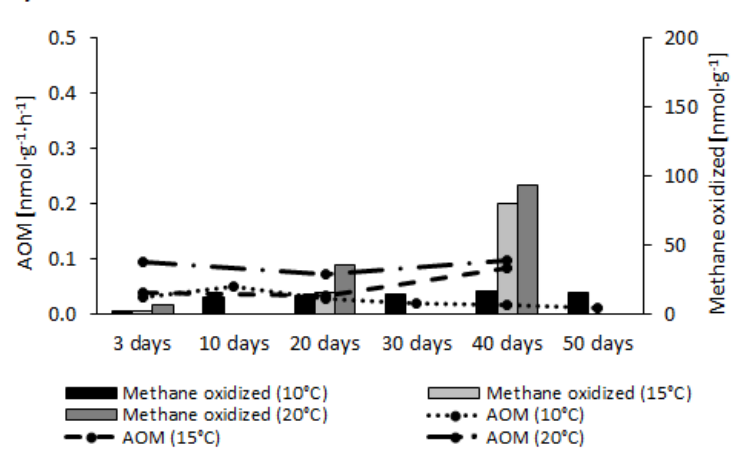

b) $5-10 \mathrm{~cm}$

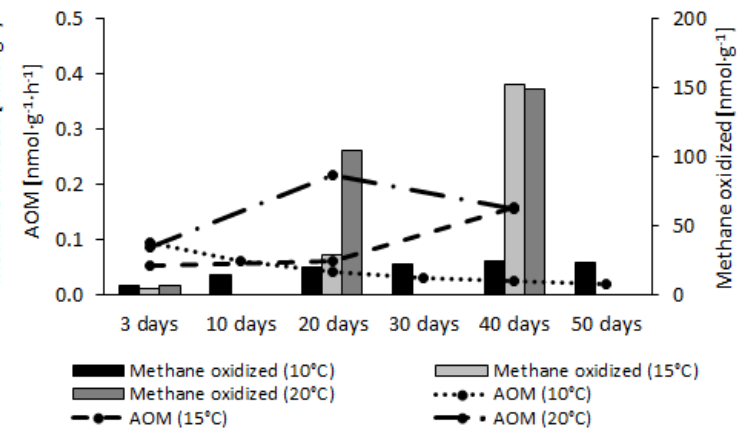

Figure 3. Changes through time in the AOM rate and amount of $\mathrm{CH}_{4}$ oxidised, for the sediment layers collected from 0-5 cm (panel a), 5-10 cm (panel b) and 10-15 cm (panel c) (He).

Correlations between AOM rate at day 40 and concentrations of nitrites, nitrates, sulphates, iron, and humic substances are shown graphically in Figure 4. 

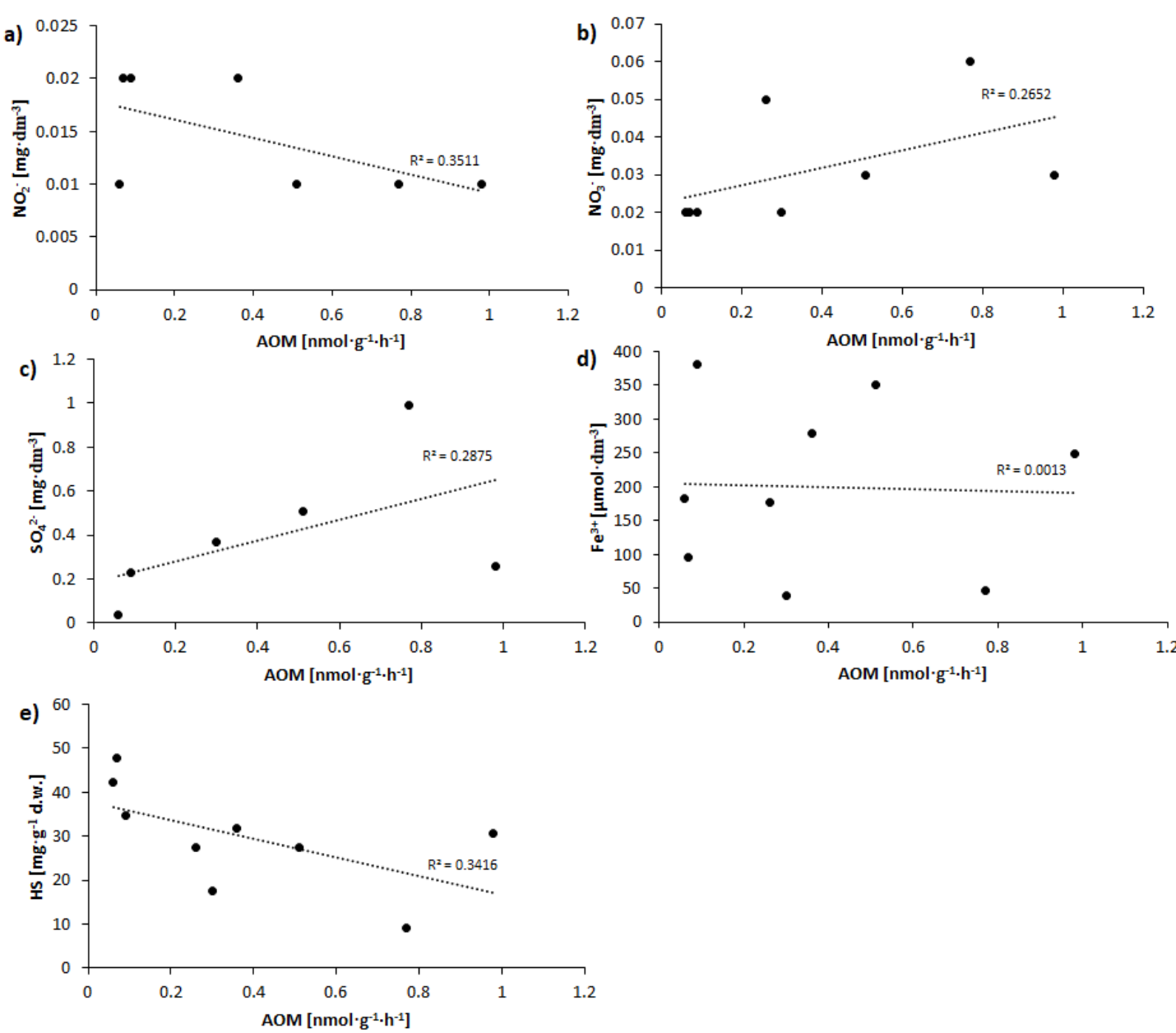

Figure 4. Correlations between $\mathrm{AOM}$ rate $\left(\mathrm{nmol} \cdot \mathrm{g}^{-1} \cdot \mathrm{h}^{-1}\right)$ at day 40 and concentrations of (a) nitrites, (b) nitrates, (c) sulphates, (d) iron, and (e) humic substances.

While no statistically significant correlations were obtained between $\mathrm{AOM}$ rate and concentrations of $\mathrm{NO}_{3}{ }^{-}\left(\mathrm{R}^{2}=0.2652\right)$ (Figure $\left.4 \mathrm{~b}\right)$ or $\mathrm{NO}_{2}{ }^{-}-\left(\mathrm{R}^{2}=0.3511\right)$ (Figure $\left.4 \mathrm{a}\right)$, upward and downward trends respectively were observed. In turn, there was also an upward trend noted for the relationship between sulphates in pore-water and the AOM rate $\left(R^{2}=0.2875\right)$ (Figure $\left.4 c\right)$. In the case of $\mathrm{Fe}^{3+}$, the $\mathrm{R}^{2}$ value was of just 0.0013 (Figure $4 \mathrm{~d}$ ), hence no relationship or tendency could be observed. On the other hand, a clear downward trend for the relationship between AOM rate and HS concentrations was to be noted $\left(\mathrm{R}^{2}=0.3416\right)$ (Figure $\left.4 \mathrm{e}\right)$.

\section{Discussion}

The results of the research into the AOM process $\left(\mathrm{He}+{ }^{13} \mathrm{CH}_{4}\right)$ reported here confirms the presence of this process in the freshwater sediments of small-scale dam reservoirs, as well as its potential importance as a link in the chain of processes involved in $\mathrm{CH}_{4}$ cycle. AOM is mainly evidenced by increased ${ }^{13} \mathrm{CO}_{2}$ concentrations in the headspace during the incubation process, with the source for this being oxidation of ${ }^{13} \mathrm{CH}_{4}$. The process involved here is engaged in by microorganisms [44,51-54], with these producing isotopically heavier $\mathrm{CO}_{2}$ as a result of their anaerobic oxidation of an isotopically-enriched compound such as ${ }^{13} \mathrm{CH}_{4}$. The amount of ${ }^{13} \mathrm{CO}_{2}$ in the headspace increased over time, perhaps also indicating curbed activity among endogenous microorganisms responsible for methanogenesis, as well as inhibited production of ${ }^{12} \mathrm{CO}_{2}$ from the decomposition of organic compounds [55,56]. The highest ${ }^{13} \mathrm{C}$-enrichment of $\mathrm{CO}_{2}$ was observed in the headspace of samples incubated at $20{ }^{\circ} \mathrm{C}$. 
In general, the process was most effective at $20{ }^{\circ} \mathrm{C}$, and data in the literature do point to a temperature-sensitive AOM process, with greatest effectiveness at $\sim 25^{\circ} \mathrm{C}[57,58]$. The fact that our samples were genuinely collected at different times of the year may also affect the AOM rate. Sediments differ in the composition and activity of microorganisms responsible for AOM from one season to another [44].

The AOM rate $\left(\mathrm{He}+{ }^{13} \mathrm{CH}_{4}\right)$ usually peaked on day 3 of the incubation process, only to decrease again thereafter. A decrease in the AOM rate has been attributed to declines in concentrations of electron acceptors [50]. After 3 days, $\mathrm{CH}_{4}$ concentrations in the headspace also declined, while $\mathrm{CO}_{2}$ concentrations went on increasing until the end of the 40 -day. A reduced $\mathrm{CO}_{2}$ concentration at day 50 may indicate gradual depletion of electron acceptors, and hence an increased relative importance of methane production probably occurring simultaneously throughout the experiment [44].

In the case of $\mathrm{He}^{13} \mathrm{CH}_{4}$ treatment, the AOM rate was lowest in the 10-15 cm sediment layer irrespective of incubation conditions. While AOM at $20^{\circ} \mathrm{C}$ was most effective in the $5-10 \mathrm{~cm}$ layer, at the temperatures of 10 and $15{ }^{\circ} \mathrm{C}$ it was the $0-5 \mathrm{~cm}$ layer that was associated with peak values. At $10^{\circ} \mathrm{C}$ and $15^{\circ} \mathrm{C}$, values for AOM rate were progressively higher in increasingly superficial layers of sediment. This likely increase in $\mathrm{CH}_{4}$ oxidation rates in upper sediment layers may reflect the increased availability of electron acceptors near the sediment-water interface [58]. While AOM may be occurring, $\mathrm{CH}_{4}$ is also being produced, in amounts that become significant in deeper sediment layers in particular. Methanogenesis entails the decomposition of "old" carbon in deeper layers of the sediment, with some of the carbon then available for anaerobic oxidation in the presence of alternative electron acceptors $[59,60]$.

AOM rates obtained for Rzeszów Reservoir differ from those noted in other aquatic ecosystems, though they still fall within the range of values presented (Table 3).

Table 3. Rates of the anaerobic oxidation of methane reported for various aquatic ecosystems.

\begin{tabular}{|c|c|c|c|c|}
\hline Name & AOM & Unit & Method & Reference \\
\hline Michigan Hollow (USA) & 0.00156 & \multirow{12}{*}{$\mathrm{nmol} \cdot \mathrm{g}^{-1} \cdot \mathrm{h}^{-1}$} & \multirow{9}{*}{$\begin{array}{l}\text { incubation } \\
\text { experiment with } \\
{ }^{13} \mathrm{CH}_{4} \text { isotope }\end{array}$} & [44] \\
\hline Channel Fen (USA) & 0.00253 & & & [44] \\
\hline Big Run Bog (USA) & 0.00142 & & & [44] \\
\hline Bog Lake Fen (USA) & 0.00254 & & & [44] \\
\hline Buckles Bog (USA) & 0.00047 & & & [44] \\
\hline Mclean Bog (USA) & 0.00088 & & & [44] \\
\hline Dryden Bog (USA) & 0.00105 & & & [44] \\
\hline Nankai Trough (Japan) & 15.63 & & & [27] \\
\hline Eckernforde Bay (Germany) & 11920 & & & {$[30,31]$} \\
\hline Monterey Bay (USA) & 5.75 & & \multirow{3}{*}{$\begin{array}{c}\text { incubation } \\
\text { experiment } \\
\text { without }{ }^{13} \mathrm{CH}_{4} \\
\text { isotope }\end{array}$} & {$[28,29]$} \\
\hline $\begin{array}{c}\text { Gulf of Cadiz } \\
\text { (Portugal/Spain) } \\
\text { Black Sea }\end{array}$ & 384 & & & {$[32,33]$} \\
\hline $\begin{array}{l}\text { (Bulgaria/Georgia/Russia/ } \\
\text { Romania/Turkey/Ukraine) }\end{array}$ & 27 & & & [34] \\
\hline
\end{tabular}

On average, values obtained for AOM rate were 100 times those noted for wetlands and bogs located in the United States, while only being respectively one-thousandth or one-hundredth of those characterising the Eckernforde Bay (Germany) or Gulf of Candiz. Such a large differentiation in the obtained values of AOM rate is still unclear and requires further research. The process is complex and depends on many factors, e.g., availability and concentration of alternative electron acceptors, parameters of sediments or presence and number of microorganisms participating in AOM. Equally significant differences are noted for methane emissions from reservoirs all around the world. $\mathrm{CH}_{4}$ fluxes differ not only between reservoirs located in different climatic zones, but also between reservoirs of the same zone and even within one reservoir between research stations. According to research conducted in Rzeszów Reservoir in 2009-2012 and 2018-2019 [7,61], average fluxes of 
methane at the water-atmosphere interface are very high and even exceed the values described for large tropical reservoirs.

When analyzing the data presented for various aquatic ecosystems, it should be taken into account that the AOM rates in vitro may differ from the AOM rate in situ (depending on the height of the water column above the sediment). The reason for this may be different hydrostatic pressure under natural and laboratory conditions. Theoretically, elevated hydrostatic pressures favor AOM, causes an increase in methane solubility and, consequently, an increase in its bioavailability [62], but the research results do not give a definite answer in this matter. For example, Cassarini [62] studied the impact of pressure gradients $(0.45,10,20,40 \mathrm{MPa})$ on the efficiency of the AOM. The author obtained the highest rate at $1{ }^{\circ} \mathrm{C}$ and at low pressure $(0.45 \mathrm{MPa})$, indicating that active ANME (anaerobic methane-oxidizing archaea) preferred scarce methane availability. Other researchers $[30,63]$ obtained the highest AOM rate at $0.1 \mathrm{MPa}$ and $15^{\circ} \mathrm{C}$. In contrast, the highest specific $\mathrm{AOM}$ rate was obtained with sediments incubated at pressure of $6 \mathrm{MPa}$ and at $20^{\circ} \mathrm{C}$ [64]. Additionally, Krüger [65], Nauhaus [66] and Zhang [32] showed a strong positive relation of the activity of the AOM microorganisms with pressure even up to $12 \mathrm{MPa}$.

Different AOM rates in situ and in vitro can also be caused by different oxidation-reduction conditions. It mainly applies to surface sediment layers, for which the AOM rate in the natural environment may be lower due to highly probable presence of oxygen.

Undoubtedly, the AOM process depends on the availability of potential electron acceptors. The impact of these acceptors on $\mathrm{AOM}$ rate was determined, with pore-water analysed for this purpose, in relation to its $\mathrm{NO}_{2}{ }^{-}, \mathrm{NO}_{3}{ }^{-}, \mathrm{SO}_{4}{ }^{2-}$, and $\mathrm{Fe}^{3+}$ concentrations in the $0-5,5-10$, and 10-15 cm layers of sediment. Additionally, the humic substances were determined for sediments first dried and then milled.

Concentrations of $\mathrm{NO}_{3}{ }^{-}$in the reservoir sediments varied from 0.017 to $0.973 \mathrm{mg} \cdot \mathrm{dm}^{-3}$, while those of $\mathrm{NO}_{2}{ }^{-}$were in the $0.009-0.017 \mathrm{mg} \cdot \mathrm{dm}^{-3}$ range. These values were either below or in the lower range of concentrations noted in sediments whose AOM process was coupled with denitrification $[67,68]$. In turn, concentrations of $\mathrm{SO}_{4}{ }^{2-}$ ranged from $0.036-13.867 \mathrm{mg} \cdot \mathrm{dm}^{-3}$. No statistically significant correlations were obtained between $\mathrm{AOM}$ rate and concentrations of $\mathrm{SO}_{4}{ }^{2-}, \mathrm{NO}_{3}{ }^{-}$or $\mathrm{NO}_{2}{ }^{-}$. However, there was an upward trend noted for the relationship between nitrates and sulphates (except for nitrites) in pore-water and the AOM rate.

The anaerobic oxidation of methane associated with sulphate reduction (AOM-SR) occurs at $\mathrm{SO}_{4}{ }^{2-}$ concentrations below $10 \mathrm{mg} \cdot \mathrm{dm}^{-3}$ [69], and such concentrations were obtained (except in the $0-5 \mathrm{~cm}$ layer at $\left.15{ }^{\circ} \mathrm{C}\right)$. Nevertheless, there is insufficient evidence to confirm AOM-SR activity in Rzeszów Reservoir sediments.

Concentrations of $\mathrm{Fe}^{3+}$ and HS ranged from 39.45 to $380.57 \mu \mathrm{mol} \cdot \mathrm{dm}^{-3}$ and 11.9 to $34.9 \mathrm{mg} \cdot \mathrm{g}^{-1}$ d.w., respectively. In the case of $\mathrm{Fe}^{3+}$, no relationship or tendency could be observed, but there was a downward trend for the relationship between AOM rate and HS concentrations.

Results presented by Gupta (2011) [44] show that, other than in the case of $\mathrm{SO}_{4}{ }^{2-}$, significant dependent relationships between concentrations of ions and $\mathrm{AOM}$ rate were lacking. On the other hand, Deutzmann and Schink (2011) [68] observed a negligible impact of $\mathrm{SO}_{4}{ }^{2-}$ on the dynamics of $\mathrm{AOM}$, while $\mathrm{NO}_{3}{ }^{-}$and $\mathrm{Fe}^{3+}$ were found to intensify the oxidation of methane significantly. This all therefore suggests a need to continue research into the AOM process in freshwater ecosystems, in order for a thorough acquaintanceship with the mechanisms and parameters underpinning AOM to be gained. Previous studies have shown complex relationships with the presence of metals, sulphates or humic substances $[25,59,70-73]$. It is possible that the combination of electron acceptors and their pathways for $\mathrm{CH}_{4}$ oxidation may be present in the sediments from Rzeszów Reservoir.

\section{Conclusions}

As detailed in this paper, analytical work on sediments $\left(\mathrm{He}+{ }^{13} \mathrm{CH}_{4}\right.$ experiment) from Poland's Rzeszów Reservoir sustains the following conclusions: 
- Anaerobic oxidation of methane ( $\mathrm{AOM})$ is a process occurring in freshwater sediments, i.e., at Rzeszów, given that a ${ }^{13} \mathrm{CH}_{4}$ isotopic marker added in the course of incubation trials underwent systematic oxidation to ${ }^{13} \mathrm{CO}_{2}$. A capacity to oxidise ${ }^{13} \mathrm{CH}_{4}$ to ${ }^{13} \mathrm{CO}_{2}$ in this way is attributed to microorganisms responsible for AOM.

- AOM rates were higher at higher temperatures, such that methane was found to oxidise most intensively at $20^{\circ} \mathrm{C}$, irrespective of the sediment layer under study. Incubation at either 10 or $15{ }^{\circ} \mathrm{C}$ sustained rates only one-fifth as high on average.

- AOM proved most effective on day 3 of incubation, with a sharp decline in rate proceeding thereafter. After day $3, \mathrm{CH}_{4}$ concentrations also decreased, while those of $\mathrm{CO}_{2}$ continued to rise through to day 50 (at $10^{\circ} \mathrm{C}$ ). On day 50 of the research, a decline in $\mathrm{CO}_{2}$ concentration could finally be observed, perhaps as a sign of the gradual depletion of electron acceptors participating in $\mathrm{AOM}$, with a growth in the relative importance of the methanogenesis ongoing simultaneously then making itself felt.

- AOM rates noted here differ from those reported for other aquatic ecosystems. While average rates were hundred times those seen in certain US wetlands, they were respectively just one-hundredth or one-tenth of those obtained for an oceanic trough (Japan) or a bay (USA).

- While a prominent role in the dynamics of the AOM process may be played by electron acceptors present in pore-water (like the $\mathrm{NO}_{3}{ }^{-}, \mathrm{SO}_{4}{ }^{2-}$ and $\mathrm{Fe}^{3+}$ ions studied) or in sediments as such (humic substances), statistically significant correlations between concentrations and AOM rates were not obtained. Previous research into AOM in other aquatic ecosystems suggests a complex relationship between respective electron acceptors and the pathways to methane oxidation they are involved in, and such dependent relationships are possibly likewise present in Rzeszów Reservoir.

Supplementary Materials: The following are available online at http://www.mdpi.com/2073-4441/12/2/398/s1, Figure S1. Changes in concentration of $\mathrm{CH}_{4}$ (black) and $\mathrm{CO}_{2}$ (grey) over time, in the different sediment layers and at different temperatures $\left(\mathrm{He}+{ }^{13} \mathrm{CH}_{4}\right)$. Figure S2. Changes in concentration of $\mathrm{CH}_{4}$ (black) and $\mathrm{CO}_{2}$ (grey) over time, in the different sediment layers and at different temperatures $(\mathrm{He})$. Figure S3. Change of ${ }^{13} \mathrm{C}$ AP over time for incubations conducted at different temperatures in the 0-5, 5-10 and 10-15 cm sediment layers $\left(\mathrm{He}^{13} \mathrm{CH}_{4}\right)$.

Author Contributions: Conceptualization, D.S.; methodology, D.S. and R.G.-R.; Formal analysis, D.S.; investigation, D.S.; resources, D.S.; data curation, D.S.; writing—original draft preparation, D.S.; writing-review and editing, R.G.-R.; visualization, D.S.; supervision, R.G.-R.; funding acquisition, R.G.-R. All authors have read and agreed to the published version of the manuscript.

Funding: This research was funded by the National Science Centre Poland, via Grant No. 2017/25/B/ST10/00981.

Conflicts of Interest: The authors declare no conflict of interest.

\section{References}

1. Rhee, T.S.; Kettle, A.J.; Andreae, M.O. Methane and nitrous oxide emissions from the ocean: A reassessment using basin- observations in the Atlantic. J. Geophys. Res. Atmos. 2009, 114, 1-20. [CrossRef]

2. Verpoorter, C.; Kutser, T.; Seekell, D.A.; Tranvik, L.J. A global inventory of lakes based on high-resolution satellite imagery. Geophys. Res. Lett. 2014, 41, 6396-6402. [CrossRef]

3. Downing, J.A.; Prairie, Y.T.; Cole, J.J.; Duarte, C.M.; Tranvik, L.J.; Striegl, R.G.; McDowell, W.H.; Kortelainen, P.; Caraco, N.F.; Melack, J.M.; et al. The global abundance and size distribution of lakes, ponds, and impoundments. Limnol. Oceanogr. 2006, 51, 2388-2397. [CrossRef]

4. Bastviken, D.; Tranvik, L.; Downing, J.A.; Crill, P.M.; Enrich-Prast, A. Freshwater methane emissions offset the continental carbon sink. Science 2011, 331, 50. [CrossRef]

5. Holgerson, M.A.; Raymond, P.A. Large contribution to inland water $\mathrm{CO}_{2}$ and $\mathrm{CH}_{4}$ emissions from very small ponds. Nat. Geosci. 2016, 9, 222-226. [CrossRef]

6. Saunois, M.; Jackson, R.B.; Bousquet, P.; Boulter, B.; Canadell, J.G. The growing role of methane in anthropogenic climate change. Environ. Res. Lett. 2016, 11, 120207. [CrossRef]

7. Gruca-Rokosz, R. Dynamics of carbon greenhouse gases in reservoirs: Production pathways, emissions to atmosphere (in Polish). Oficyna Wydawnicza Politechniki Rzeszowskiej 2015, 1-132. 
8. Zehnder, A.J.B.; Stumm, W. Geochemistry and biogeochemistry of anaerobic habitats. In Biology of Anaerobic Microorganisms; Zehnder, A.J.B., Ed.; John Wiley \& Sons: New York, NY, USA, 1988; pp. 1-38.

9. Den Heyer, C.; Kalff, J. Organic Matter Mineralization Rates in Sediments: A Within- and Among- Lake Study. Limnol. Oceanogr. 1998, 43, 695-705. [CrossRef]

10. Bastviken, D. Anoxic Degradation of Organic Matter in Lakes-Implications for Carbon Cycling and Aquatic Food Webs. Ph.D. Thesis, Department of Water and Environmental Studies, Linköping University, Linköping, Sweden, 2002; pp. 3-55.

11. Wetzel, R.G. Limnology_Lake and River Ecosystems, 3rd ed.; Academic Press: San Diego, CA, USA, 2001; pp. 631-664.

12. Thauer, R.K.; Shima, S. Methane as fuel for anaerobic microorganisms. Ann. N. Y. Acad. Sci. 2008, 1125, 158-170. [CrossRef]

13. Strous, M.; Jetten, M.S.M. Anaerobic oxidation of methane and ammonium. Annu. Rev. Microbiol. 2004, 58, 99-117. [CrossRef]

14. Shima, S.; Thauer, R.K. Methyl-coenzyme M reductase and the anaerobic oxidation of methane in methanotrophic. Archaea. Curr. Opin. Microbiol. 2005, 8, 643-648. [CrossRef] [PubMed]

15. Valentine, D.L.; Reeburgh, W.S. New perspectives on anaerobic methane oxidation. Environ. Microbiol. 2000, 2, 477-484. [CrossRef] [PubMed]

16. Smemo, K.A.; Yavitt, J.B. Anaerobic oxidation of methane: An underappreciated aspect of methane cycling in peatland ecosystems? Biogeosciences 2011, 8, 779-793. [CrossRef]

17. Blazewicz, S.J.; Petersen, D.G.; Waldrop, M.P.; Firestone, M.K. Anaerobic oxidation of methane in tropical and boreal soils: Ecological significance in terrestrial methane cycling. J. Geophys. Res. Biogeosci. 2012, 117, G02033. [CrossRef]

18. Boetius, A.; Ravenschlag, K.; Schubert, C.J.; Rickert, D.; Widdel, F.; Gieseke, A.; Amann, R.; Jørgensen, B.B.; Witte, U.; Pfannkuche, O. A marine microbial consortium apparently mediating anaerobic oxidation of methane. Nature 2000, 407, 623-626. [CrossRef] [PubMed]

19. Deutzmann, J.S.; Stief, P.; Brandes, J.; Schink, B. Anaerobic methane oxidation coupled to denitrification is the dominant methane sink in a deep lake. PNAS 2014, 111, 18273-18278. [CrossRef] [PubMed]

20. Reeburgh, W.S. Methane consumption in Cariaco Trenchwaters and sediment. Earth Planet. Sci. Lett. 1976, 28, 337-344. [CrossRef]

21. Schubert, C.J.; Lucas, F.S.; Durisch-Kaiser, E.; Stierli, R.; Diem, T.; Scheidegger, O.; Vazquez, F.; Müller, B. Oxidation and emission of methane in a monomictic lake (Rotsee, Switzerland). Aquat. Sci. 2010, 72, 455-466. [CrossRef]

22. Zehnder, A.J.; Brock, T.D. Methane formation and methane oxidation by methanogenic bacteria. J. Bacteriol. 1979, 137, 420-432. [CrossRef]

23. Reeburgh, W. Oceanic methane biogeochemistry. Chem. Rev. 2007, 107, 486-513. [CrossRef]

24. Segarra, K.E.A.; Schubotz, F.; Samarkin, V.; Yoshinaga, M.Y.; Hinrichs, K.U.; Joye, S.B. High rates of anaerobic methane oxidation in freshwater wetlands reduce potential atmospheric methane emissions. Nat. Commun. 2015, 6, 7477. [CrossRef] [PubMed]

25. Sivan, O.; Adler, M.; Pearson, A.; Gelman, F.; Bar-Or, I.; John, S.C.; Eckert, W. Geochemical evidence for iron-mediated anaerobic oxidation of methane. Limnol. Oceanogr. 2011, 56, 1536-1544. [CrossRef]

26. Gruca-Rokosz, R.; Tomaszek, J.A.; Koszelnik, P.; Czerwieniec, E. Methane and carbon dioxide fluxes at the sediment-water interface in reservoir. Pol. J. Environ. Study 2011, 20, 81-86.

27. Aoki, M.; Ehara, M.; Saito, Y.; Yoshioka, H.; Miyazaki, M.; Saito, Y.; Miyashita, A.; Kawakami, S.; Yamaguchi, T.; Ohashi, A.; et al. A Long-Term Cultivation of an Anaerobic Methane-Oxidizing Microbial Community from Deep-Sea Methane-Seep Sediment Using a Continuous-Flow Bioreactor. PLoS ONE 2014, 9, e105356. [CrossRef]

28. Girguis, P.R.; Orphan, V.J.; Hallam, S.J.; DeLong, E.F. Growth and methane oxidation rates of anaerobic methanotrophic archaea in a continuous-flow bioreactor. Appl. Environ. Microbiol. 2003, 69, 5472-5482. [CrossRef]

29. Girguis, P.R.; Cozen, A.E.; DeLong, E.F. Growth and population dynamics of anaerobic methane-oxidizing archaea and sulfate-reducing bacteria in a continuous-flow bioreactor. Appl. Environ. Microbiol. 2005, 71, 3725-3733. [CrossRef] 
30. Meulepas, R.J.W.; Jagersma, C.G.; Gieteling, J.; Buisman, C.J.N.; Stams, A.J.M.; Lens, P.N.L. Enrichment of anaerobic methanotrophs in a sulfate-reducing membrane bioreactors. Biotechnol. Bioeng. 2009, 104, 458-470. [CrossRef]

31. Jagersma, G.C.; Meulepas, R.J.W.; Jong, I.H.; Gieteling, J.; Klimiuk, A.; Schouten, S.; Damsté, J.S.S.; Lens, P.N.L.; Stams, A.J.M. Microbial diversity and community structure of a highly active anaerobic methane-oxidizing sulfate-reducing enrichment. Environ. Microbiol. 2009, 12, 3223-3232. [CrossRef]

32. Zhang, Y.; Henriet, J.P.; Bursens, J.; Boon, N. Stimulation of in vitro anaerobic oxidation of methane rate in a continuous high-pressure bioreactor. Bioresour. Technol. 2010, 101, 3132-3138. [CrossRef]

33. Zhang, Y.; Maignien, L.; Zhao, X.; Wang, F.; Boon, N. Enrichment of a microbial community performing anaerobic oxidation of methane in a continuous high-pressure bioreactor. BMC Microbiol. 2011, 11, 137. [CrossRef]

34. Wegener, G.; Boetius, A. An experimental study on short-term changes in the anaerobic oxidation of methane in response to varying methane and sulfate fluxes. Biogeosciences 2009, 6, 867-876. [CrossRef]

35. Koszelnik, P.; Tomaszek, J.A. Loading of the Rzeszów reservoir with biogenic elements—Mass balance. Environ. Prot. Eng. 2002, 28, 99-106.

36. Gruca-Rokosz, R.; Tomaszek, J. Methane and Carbon Dioxide in the Sediment of a Eutrophic Reservoir: Production Pathways and Diffusion Fluxes at the Sediment-Water Interface. Water Air Soil Pollut. 2015, 226, 16. [CrossRef] [PubMed]

37. Gruca-Rokosz, R.; Koszelnik, P. Production pathways for $\mathrm{CH}_{4}$ and $\mathrm{CO}_{2}$ in sediments of two freshwater ecosystems in south-eastern Poland. PLoS ONE 2018, 13, e0199755. [CrossRef] [PubMed]

38. Reeburgh, W.S. An improved interstitial water sampler. Limnol. Oceanogr. 1967, 12, 163-165. [CrossRef]

39. Ostrowska, A.; Gawliński, S.; Szczubiałka, Z. Methods of Analysis and Assessment of Soil and Plant Properties (in Polish); Instytut Ochrony Środowiska: Warszawa, Poland, 1991.

40. Holmer, M.; Wildish, D.; Hargrave, B. Organic Enrichment from Marine Finfish Aquaculture and Effects on Sediment Biogeochemical Processes. In Environmental Effects of Marine Finfish Aquaculture; Springer: Berlin/Heidelberg, Germany, 2005; Volume 5, pp. 181-206. [CrossRef]

41. Zimmermann, C.F.; Keefe, C.W.; Bashe, J. Method 440.0 Determination of Carbon and Nitrogen in Sediments and Particulates/Coastal Waters Using Elemental Analysis; NER Laboratory, USEPA: Cincinnati, OH, USA, 1997. Available online: http://www.epa.gov/nerlcwww/m440_0.pdf (accessed on 19 August 2019).

42. Griffith, S.M.; Schnitzer, M. Analytical characteristics of humic and fiilvic acids extracted from tropical volcanic soils. Soil Sci. Soc. Am. J. 1975, 39, 861-867. [CrossRef]

43. Viollier, E.; Inglett, P.W.; Hunter, K.; Roychoudhury, A.N.; Van Cappellen, P. The ferrozine method revisited: $\mathrm{Fe}(\mathrm{II}) / \mathrm{Fe}(\mathrm{III})$ determination in natural waters. Appl. Geochem. 2000, 15, 785-790. [CrossRef]

44. Gupta, V. Anaerobic Oxidation of Methane in Northern Peatland. Ph.D. Thesis, Department of Geography, University of Toronto, Toronto, ON, Canada, December 2011.

45. Shi, Y.; Wang, Z.; He, C.; Zhang, X.; Sheng, L.; Ren, X. Using 13 C isotopes to explore denitrification-dependent anaerobic methane oxidation in a paddy-peatland. Sci. Rep. 2017, 7, 40848. [CrossRef]

46. Bednarek, A.; Zalewski, M. Potential effects of enhancing denitrification rates in sediments of the Sulejow reservoir. Environ. Prot. Eng. 2007, 33, 35-43.

47. Haziak, T.; Czaplicka-Kotas, A.; Slusarczyk, Z.; Szalińska, E. Spatial changes of zinc concentrations in the Czorsztyn Reservoir sediments (in Polish). Inżynieria i Ochrona Środowiska 2013, 16, 57-68.

48. Koszelnik, P. Sources and Distribution of Biogenic Elements on the Example of the Solina-Myczkowce Dam Reservoir (in Polish); Oficyna Wydawnicza Politechniki Rzeszowskiej: Rzeszów, Poland, 2009; pp. 1-147.

49. Piwińska, D.; Gruca-Rokosz, R.; Bartoszek, L.; Czarnota, J. Spatial Diversity Characterising Certain Chemical Substances in Sediments of Besko Reservoir. J. Ecol. Eng. 2018, 19, 104-112. [CrossRef]

50. Fan, L.; Shahbaz, M.; Ge, T.; Wu, J.; Dippold, M.; Thiel, V.; Kuzyakov, Y.; Dorodnikov, M. To shake or not to shake: ${ }^{13} \mathrm{C}$-based evidence on anaerobic methane oxidation in paddy soil. Soil Biol. Biochem. 2019, 133, 146-154. [CrossRef]

51. Basiliko, N.; Yavitt, J.B.; Dees, P.M.; Merkel, S.M. Methane Biogeochemistry and Methanogen Communities in Two Northern Peatland Ecosystems, New York State. Geomicrobiol. J. 2003, 20, 563-577. [CrossRef]

52. Dettling, M.D.; Yavitt, J.B.; Zinder, S.H. Control of organic carbon mineralization by alternative electron acceptors in four peatlands, Central New York State, USA. Wetlands 2006, 26, 917. [CrossRef] 
53. Godin, A.; McLaughlin, J.W.; Webster, K.; Packalen, M.; Basiliko, N. Methane and methanogen community dynamics across a boreal peatland nutrient gradient. Soil Biol. Biochem. 2012, 48, 96-105. [CrossRef]

54. Martinez-Cruz, K.; Sepulveda-Jauregui, A.; Casper, P.; Anthony, K.W.; Smemo, K.A.; Thalasso, F. Ubiquitous and significant anaerobic oxidation of methane in freshwater lake sediments. Water Res. 2018, 144, 332-340. [CrossRef]

55. Szal, D.; Gruca-Rokosz, R. Denitrification-Dependent Anaerobic Oxidation of Methane in Freshwater Sediments of Reservoirs in SE Poland. J. Ecol. Eng. 2019, 20, 218-227. [CrossRef]

56. Li, L.; Xue, S.; Xi, J. Anaerobic oxidation of methane coupled to sulfate reduction: Consortium characteristics and application in co-removal of H2S and methane. J. Environ. Sci. 2019, 76, 238-248. [CrossRef]

57. Hoehler, T.M.; Alperin, M.J.; Albert, D.B.; Martens, C.S. Field and laboratory studies of methane oxidation in an anoxic marine sediment: Evidence for a methanogen-sulfate reducer consortium. Glob. Biogeochem. Cycles 1994, 8, 451-463. [CrossRef]

58. Smemo, K.A. Methane Cycling in Northern Peatland Ecosystems. A Potential Role for Anaerobic Methane Oxidation. Ph.D. Thesis, Cornell University, Ithaca, NY, USA, 2003; p. 138.

59. Smemo, K.; Yavitt, J.B. Evidence for Anaerobic $\mathrm{CH}_{4}$ Oxidation in Freshwater Peatlands. Geomicrobiol. J. 2007, 24, 583-597. [CrossRef]

60. Broman, E. Observation of Methanogenesis and Potential Iron-Dependent Anaerobic Oxidation of Methane in Old Lake Sediments, A Study of Two Boreal Forest Lakes. Master's Thesis, Uppsala University, Uppsala, Sweden, 2013.

61. Gruca-Rokosz, R. Quantitative fluxes of the greenhouse gases $\mathrm{CH}_{4}, \mathrm{CO}_{2}$ from the surfaces of selected Polish reservoirs. Atmosphere 2019. submitted.

62. Cassarini, C. Anaerobic Oxidation of Methane Coupled to Reduction of Different Sulfur Compounds as Electron Acceptors in Bioreactors; CRC Press: Boca Raton, FL, USA, 2017.

63. Meulepas, R.J.W.; Jagersma, C.G.; Khadem, A.F.; Buisman, C.J.N.; Stams, A.J.M.; Lens, P.N.L. Effect of environmental conditions on sulfate reduction with methane as electron donor by an Eckernförde Bay enrichment. Environ. Sci. Technol. 2009, 43, 6553-6559. [CrossRef] [PubMed]

64. Deusner, C.; Meyer, V.; Ferdelman, T. High-pressure systems for gas-phase free continuous incubation of enriched marine microbial communities performing anaerobic oxidation of methane. Biotechnol. Bioeng. 2009, 105, 524-533. [CrossRef] [PubMed]

65. Krüger, M.; Treude, T.; Wolters, H.; Nauhaus, K.; Boetius, A. Microbial methane turnover in different marine habitats. Palaeogeogr. Palaeoclimatol. Palaeoecol. 2005, 227, 6-17. [CrossRef]

66. Nauhaus, K.; Boetius, A.; Kruger, M.; Widdel, F. In vitro demonstration of anaerobic oxidation of methane coupled to sulphate reduction in sediment from a marine gas hydrate area. Environ. Microbiol. 2002, 4, 296-305. [CrossRef]

67. Ettwig, K.F.; van Alen, T.; van de Pas-Schoonen, K.T.; Jetten, M.S.M.; Strous, M. Enrichment and molecular detection of denitrifying methanotrophic bacteria of the NC10 phylum. Appl. Environ. Microbiol. 2009, 75, 3656-3662. [CrossRef]

68. Deutzmann, J.; Schink, B. Anaerobic Oxidation of Methane in Sediments of Lake Constance, an Oligotrophic Freshwater Lake. Appl. Environ. Microbiol. 2011, 77, 4429-4436. [CrossRef]

69. Weber, H.S.; Habicht, K.S.; Thamdrup, B. Anaerobic Methanotrophic Archaea of the ANME-2d Cluster Are Active in a Low-sulfate, Iron-rich Freshwater Sediment. Front Microbiol. 2017, 12, 619. [CrossRef]

70. Egger, M.; Rasigraf, O.; Sapart, C.J.; Jilbert, T.; Jetten, M.S.M.; Röckmann, T.; Van Der Veen, C.; Bânda, N.; Kartal, B.; Ettwig, K.F.; et al. Iron-mediated anaerobic oxidation of methane in brackish coastal sediments. Environ. Sci.Technol. 2015, 49, 277-283. [CrossRef]

71. He, Z.; Zhang, Q.; Feng, Y.; Luo, H.; Pan, X.; Michael, G. Microbiological and environmental significance of metal-dependent anaerobic oxidation of methane. Sci. Total Environ. 2018, 610, 759-768. [CrossRef]

72. Nordi, K.; Thamdrup, B.; Schubert, C. Anaerobic oxidation of methane in an iron-rich Danish freshwater lake sediment. Limnol. Oceanogr. 2013, 58, 546-554. [CrossRef]

73. Valenzuela, E.I.; Prieto-Davó, A.; López-Lozano, N.E.; Hernández-Eligio, A.; Vega-Alvarado, L.; Juárez, K.; García-González, A.S.; López, M.G.; Cervantes, F.J. Anaerobic methane oxidation driven by microbial reduction of natural organic matter in a tropical wetland. Appl. Environ. Microbiol. 2017, 83. [CrossRef]

(C) 2020 by the authors. Licensee MDPI, Basel, Switzerland. This article is an open access article distributed under the terms and conditions of the Creative Commons Attribution (CC BY) license (http://creativecommons.org/licenses/by/4.0/). 